Published in final edited form as:

Curr Opin Immunol. 2017 August ; 47: 44-51. doi:10.1016/j.coi.2017.06.005.

\title{
Old and new adjuvants
}

\author{
Amy S. McKee ${ }^{a, b}$ and Philippa Marrack ${ }^{a, b, c}$ \\ ${ }^{1}$ Department of Medicine, University of Colorado Anschutz Medical Campus, Aurora, CO 80045, \\ USA \\ ${ }^{2}$ Department of Immunology and Microbiology, University of Colorado Anschutz Medical Campus, \\ Aurora, CO 80045, USA \\ ${ }^{3}$ Department of Biomedical Research, National Jewish Health, 1400, Jackson St., Denver, CO \\ 80206, USA
}

\section{Introduction}

Unknowingly, as an accident of the material used, or deliberately, adjuvants have been used to improve vaccines for as long as vaccines have been in use. For example, for some centuries, small doses of live smallpox viruses were used in China, Turkey, Persia and elsewhere to immunize healthy people against the disease [1]. The live viruses in this case expressed intrinsic adjuvants in the shape of the viral nucleic acids and components of the virus coat. Later, Jenner's famous cowpox vaccine [2] again brought with it adjuvants derived from the live virus, in a context that was less risky than smallpox itself, since the cowpox virus reproduced less well and caused less attendant pathology than smallpox infection in people. So, we could view the cowpox vaccine as the first successful use of what was essentially an attenuated live virus vaccine in humans. Use of what are now presumed to have been live attenuated viruses in vaccines continued as the viruses responsible for various diseases were discovered. For example, rabies virus that had been passaged in rabbits' brains and then dried constituted the first rabies vaccine, produced by Pasteur and Roux [3,4] and attenuated yellow fever virus became the standard vaccine for that disease (all reviewed in Nunnally et al [5]).

Meanwhile soluble toxins produced by various infections were discovered. Amongst these were the diphtheria and tetanus toxins, discovered respectively by Roux and Yersin in 1888 [6] and by Faber and Tizzoni and Cattani [7,8]. Von Behring and others found that immunization with these (at the time rather impure) proteins protected animals against the disease they induced and that antisera produced against them in, for example, horses, was also protective upon transfer into intoxicated hosts [9]. To protect against intoxication by

\footnotetext{
All correspondence should be directed to amy.mckee@ucdenver.edu.
}

Publisher's Disclaimer: This is a PDF file of an unedited manuscript that has been accepted for publication. As a service to our customers we are providing this early version of the manuscript. The manuscript will undergo copyediting, typesetting, and review of the resulting proof before it is published in its final citable form. Please note that during the production process errors may be discovered which could affect the content, and all legal disclaimers that apply to the journal pertain.

Conflict of Interest

The authors declare no conflicts of interest. 
these proteins, they were sometimes given with the antisera but later Glenny and Sudmersen and Ramon $[10,11]$ realized that the toxins could be inactivated with formaldehyde and were still sufficient to induce antibody production without toxic sequelae [12]. The consequent demand for anti-toxin antibodies led to large scale immunization of horses for production of such antisera and memorable events such as the transport of life saving diphtheria anti-toxin to Nome in 1925. How did these toxin and toxoid preparations raise antisera even though they are given without obvious adjuvants? Perhaps the preparations contained contaminating bacterial products, or perhaps their partial denaturation during preparation created some adjuvant properties in the proteins themselves [13]. In attempts to improve the titers of immunized horses Ramon co-injected the antigens with various materials including tapioca and breadcrumbs [10,14], which did actually work so we can think of these common kitchen commodities as being amongst the first officially added vaccine adjuvants. At about the same time Pope had discovered that salt precipitates brought down toxins from solution and Pope and Glenny together showed that tetanus toxoid adsorbed to insoluble aluminium salts (called alum for simplicity, to refer to the several insoluble aluminum salts used in vaccines, for the rest of this article) would improve antibody responses in guinea pigs [11]. Only a few years later, trials in human populations showed that diphtheria vaccines formulated with alum protected against diphtheria intoxication much better than the previous vaccines.

Since the 1920s many new adjuvants have been added to vaccines. Here we will discuss both one of the oldest adjuvants (alum) and new adjuvants below and in other chapters in this edition.

\section{Insoluble salts and other particulate adjuvants}

Besides alum, several other particulate adjuvants, calcium phosphate, chitin and other insoluble carbohydrates and nanoparticles have been used in vaccines for humans. Viral like nanoparticles will not be considered here although the particulate nature of the virus products may in itself have some adjuvant-like qualities [15]. The viral like particles are, however, often administered with added adjuvants such as alum (for example in the Gardisil vaccine) and, in some formulations, AS04 (alum plus monophosphoryl lipid A (MPL) in Cervarix). In the USA alum is added to a number of vaccines including those for diphtheria and tetanus toxins and pertussis (DTaP), for hepatitis A and B and for the various polysaccharide conjugate vaccines (See Box 1). In Europe calcium phosphate, another insoluble metal salt, is used in DT vaccines [16-19] and was suggested as a component of influenza vaccines by Salk and others [20]. Of all these alum is by far the most widely used and studied.

Here we will focus on what is known about the adjuvant properties of alum, because of all the particulate adjuvants, it is the most studied. However, it is likely that in some regards responses to alum are related to those of other particulate materials. Reports that injection of insoluble aluminium salts led to rapid accumulation of neutrophils and other cells and granulomas at the injection site have been in the literature for many years [21-23]. The accumulation of these cells is accompanied by fibrinogen conversion to fibrin and accumulation of the tiny injected alum particles into large lumps [24]. These lumps are composed of alum particles bound together by neutrophil extracellular traps (NETs) [25-

Curr Opin Immunol. Author manuscript; available in PMC 2018 August 01. 
27]. The NETs are made up of chromatin which the neutrophils expel after engagement of fibrin previously deposited on the alum [24,28]. Do the neutrophils and other cells that are attracted to the alum and the NETs and their chromatin component have anything to do with the adjuvant properties of alum? It is difficult to evaluate the contributions of NETs since it is difficult to eliminate them entirely from injected alum. As for the accompanying chromatin, a couple of papers have suggested that host DNA may indeed increase alum's effects but host DNA is certainly not the only intrinsic adjuvant induced by alum ([29-31] but see [32]). Alum may also act simply as a particle, lysing lysosome and releasing lysosomal enzymes into the cytoplasm [33-35] or by distorting the plasma membrane of antigen presenting cells [36] and/or somehow by its ability to rapidly induce production if cytokines and chemokines [37,38].

It is well known that alum rapidly activates the NALP3 inflammasome and consequent production of the potent $\mathrm{T}$ cell stimulating cytokine, IL-1 $\beta$ [37,39-41]. Some have suggested that IL-1 $\beta$ is at the root of alum's adjuvant activity [42,43] but others have failed to confirm this notion $[37,44-46]$. Alum also, in an inflammasome independent manner, induces the release by macrophages of biologically active IL-1 $a$. However while IL- $1 a$ is required for neutrophil infiltration at the injection site, it's absence does not impact $\mathrm{T}$ or $\mathrm{B}$ cell responses after i.p. injection of antigen with the adjuvant [47]. Interestingly, the proteins involved in IL-1 signaling, MyD88 and IL-1Rs, are dispensable for the effects of alum on antibody responses after ip or im injection $[44,48,49]$ but are required for adjuvant effects of alum on IgE responses when instilled into the lung as a model particulate [50,51]. These effects are independent of the NALP3 inflammasome and appear to be related to the fact that alveolar macrophages undergo necrosis and thus release IL-1a [51] when exposed to alum whereas peritoneal macrophages do not. Thus, the confusion about the mode of action of alum may be partly due to the properties of the resident macrophages (or other cell types) located at the site of injection. For example, resident alveolar macrophages are relatively anti-inflammatory $[52,53]$, whereas the macrophages that migrate into challenged lungs are more inflammatory [54]. Thus the various conflicting data about the mode(s) of action of alum may be occasioned by use of different sites of injection or different states of the resident cells in the various experiments.

Other insoluble metal salts such as beryllium hydroxide, have adjuvant properties that enhance sensitization and disease after pulmonary exposure [55]. Beryllium hydroxide induces release of caspase-1-independent IL-1 $\alpha$ from necrotic alveolar macrophages and mediates its adjuvant effects on Th1 cells via MyD88-dependent receptors that enhance DC migration and function [56].

The fact that alum induces TH2-type responses, TFH cells and the antibody isotypes, IgG1 and IgE, that are induced by such T cells in mice is not in dispute [57-62]. However, the bias in antibody isotypes induced by alum may be less pronounced in humans [63]. In contrast to other particulate vaccine adjuvants, alum has been reported to suppress secretion of IL-12, a critical third signal for TH1 cell differentiation [64]. Perhaps this is one of the ways in which alum biases responses towards $\mathrm{T}$ cell differentiation into $\mathrm{TH} 2$ type cells. 


\section{Emulsion based adjuvants}

In 1930, Jules Freund developed the first deliberately added adjuvant that enhanced cellular immunity, a water-in-mineral oil emulsion containing heat killed Mycobacterium tuberculosis (MTb), Freud's Complete Adjuvant (CFA) [65]. It induces potent antibody responses and cellular immunity [66], but the necrotic abscesses and granulomas induced by CFA at the injection site preclude its use in human vaccines. Muramyl dipeptide expressed by MTb in CFA activates NOD2 receptors [67,68]. Incomplete Freund's adjuvant (IFA) composed of just the mineral oil component of CFA, was used in influenza vaccines in the 1950s to enhance antibody responses [69], and due to significant side effects [70] has only been studied in clinical trials of HIV and some cancer vaccines [71]. It enhances accumulation of APCs, antigen uptake and cytokine production and a non-polarized $\mathrm{TH} 1 / \mathrm{TH} 2$ response with enhanced $\mathrm{IgG1} / \mathrm{IgG} 2 \mathrm{a}$ antibody responses [72-76].

Emulsion adjuvants approved for use in human vaccines are those that contain derivatives of squalene, a steroid precursor lipid. Squalene emulsified with surfactants serves as an adjuvant (MF59 and AS03) that drives robust antibody responses, polyfunctional TH1 cells and TFH cells, and enhanced immunity to heterotypic strains of influenza [77-82]. Uniquely, antibody isotype switching is induced by MF59 in the absence of CD4 ${ }^{+} \mathrm{T}$ cells, however apparently the plasma cells making this antibody don't live for a long time in the absence of T cell help [83]. MF59 causes the production of a broader range of cytokine/

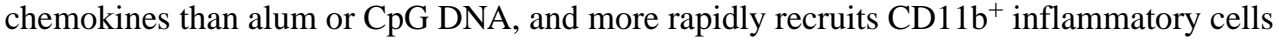
to the injection site [38]. MF59 induced antibody responses are not affected by the absence of NALP3 or caspase-1 in mice, that is, the adjuvant properties of MF59 appear to be independent of the NALP3 inflammasome. However mice lacking ASC, a protein that is involved in activation of inflammasomes, have impaired antibody $\mathrm{IgG}$ responses suggesting an inflammasome-independent mechanism by which this adaptor promotes humoral immunity [84,85]. MyD88 is involved in the adjuvant effects of MF59 on protective antibody production [85] while type I IFNs are not required [86]. TLRs and innate receptors do not respond directly to squalene in vitro [85]. Thus, MF59 may engage innate MyD88dependent cell receptors via cell injury or stress and the release of DAMPS, such as ATP [87].

\section{Innate pattern recognition receptor targeting adjuvants}

Activation of innate pattern recognition receptors promotes DC function required for polyfunctional TH1 cells, T cell memory, and CTL responses [88-92]. Targeting antigen and TLR agonists to DCs using monoclonal antibodies can improve the effects of TLR ligands [93-98] and addition of TLR ligand-targeting adjuvants to emulsions, insoluble metal salts, particles, and liposomes as delivery vehicles are more effective than soluble TLR-ligands alone [99-101].

Monophosphoryl lipid A (MPL), a diglucosamine derivative of lipopolysaccharide (LPS), has less toxic effects than LPS itself and is approved for use in human vaccines. MPL increases costimulatory molecule expression and IL-12 production by human DCs [102]. It mediates its adjuvant effects on TH1 cells via the TRIF-biased signaling pathway 
downstream of TLR4 and type I IFNs [103], drives the production of TH1 cytokines [104] and enhances the production of antigen-specific CD8 cytotoxic T lymphocytes (CTLs) [105]. Glucopyranosyl lipid A adjuvant (GLA) is a synthetic hexaacylated lipid A derivative and TLR4 agonist. It is being studied in an emulsion based adjuvant (GLA-SE) for tuberculosis, leishmaniasis and influenza vaccines [106]. MPL is unable to initiate CD14 to augment dimerization of TLR4/MD2, which drives MyD88 activation at the plasma membrane and thus primarily mediates its effects on T cells via the TRIF pathway $[103,107,108]$. In contrast, GLA drives expression of MyD88-dependent genes expression at lower doses than MPL [109], and drives expansion of polyfunctional TH1 cells, CD8 ${ }^{+} \mathrm{T}$ cells and TFH cells, via activation of both TRIF and MyD88 adaptors [110,111]. GLA-SE induces IL-12 production and TH1 cells [110]. When injected into the muscle GLA-SE accumulates in a network of subcapsular macrophages in the draining LNs, driving IL-18production [112]. These macrophages are required for B cell expansion and differentiation, antibody secretion, and TH1 responses in vaccines using GLA-SE as adjuvant.

Agonists of TLR3 (polyI:C), TLR7/8 (remiquimod, imiquimod) and TLR9 and Nod2 (muramyl dipeptide) are being studied in various formulations for clinical development. The yellow fever vaccine promotes lifelong immunity via multiple TLRs expressed on different DC subsets [113] and combination of different TLR agonists can lead to better protection than either TLR agonist alone [114]. The combination of TLR agonists is likely dependent upon the targeted pathogen, as not all combinations offer the same protective effects [115].

\section{Conclusion}

Alum adjuvanted subunit vaccines have had a profound impact on early childhood mortality largely due to their ability to induce protective antibody responses. Alum does induce small $\mathrm{CD} 8^{+} \mathrm{T}$ cell responses but does not drive CTL responses unless combined with a TLR agonist [116]. Diseases that contribute to mortality in children for which subunit vaccines have been more difficult to develop include intracellular pathogens (MTb), those with complex lifecycles (malaria), or ability to evade or disable the immune system (HIV, HPV, HSV, Influenza). Modern adjuvant strategies aim to improve vaccination to these more difficult targets by promoting polyfunctional TH1 and CTL memory cells and differentiation of TFH cells to drive long lived heterotypic antibody-mediated protection [92]. Formulations that use the benefits of both of older antigen delivery systems and adjuvants that promote cellular stress/DAMP release with newer adjuvants or delivery systems that target specific DCs and/or innate PRR, may effective vaccines to offer safe protection against pathogens that have historically evaded successful vaccine strategies.

\section{Acknowledgments}

AM is supported by National Institutes of Health [grant numbers HL126736, ES025534 and HL135872-01]. PM is supported by NIH grants AI-18785 and AI118688.

\section{References}

1. Plotkin, SA., Mortimer, EA. Short history of vaccination. 2. Philadelphia: W.B. Saunders Co; 1994.

Curr Opin Immunol. Author manuscript; available in PMC 2018 August 01. 
2. Jenner, E. I. An Inquiry Into the Causes and Effects of the Variolae Vaccinae, Or Cow-Pox. In: Eliot, C., editor. The Three Original Publications on Vaccination Against Smallpox. Vol. XXXVIII. New York: P.F. Collier \& Son, 1909-14; 1798.

3. Pearce J. Louis Pasteur and Rabies: a brief note. Journal of Neurology, Neurosurgery \& Psychiatry. 2002; 73:82-82.

4. Theodorides J. Pasteur and Rabies, the British Connection. J R Soc Med. 1989; 82:488-490. [PubMed: 2674432]

5. Nunnally, BK. Vaccine Reference Standards. Springer Berlin Heidelberg; 2015. p. 563-572.Edited by:

6. Yersin R. Contribution à l'Étude de la Diphtérie [Contribution to the study of diphtheria]. Annales de l'Institut Pasteur. 1888

7. Faber K. Die Pathogenie des Tetanus. Berl klin Wochenschr. 1890; 27:717-720.

8. Tizzoni G, Cattani G. Untersuchungen uber das Tetanusgift. Arch Exp Pathol Pharmakol. 1890

9. Roux ME, Martin ML, Chaillou MA. Trois cents cas de diphterie traites par le serum antidiphterique. Ann Inst Pasteur. 1894:640-662.

10. Ramon G. Sur l'augmentation anormale de l'antitoxine chez les chevaux producteurs de serum antidiphterique. Bull Soc Cetr Med Vet. 1925:227-234.

11. Glenny AT, Südmersen HJ. Notes on the Production of Immunity to Diphtheria Toxin. Journal of Hygeine. 1921; 20:176-220.

12. Geny, Blandine, Popoff, Michel R. Bacterial protein toxins and lipids: role in toxin targeting and activity. Biology of the Cell. 2006; 98:633-651. [PubMed: 17042741]

13. Dresser DW. An assay for adjuvanticity. Clin Exp Immunol. 1968; 3:877-888. [PubMed: 4179956]

14. Ramon, M. Sur in production des antitoxines. Vol. 181. Paris: C. R. Acad. Sci.; 1925.

15. Da Silva DM, Fausch SC, Verbeek JS, Kast WM. Uptake of human papillomavirus virus-like particles by dendritic cells is mediated by Fcgamma receptors and contributes to acquisition of $\mathrm{T}$ cell immunity. J Immunol. 2007; 178:7587-7597. [PubMed: 17548594]

16. Relyveld EH, Bizzinii B, Gupta RK. Rational approaches to reduce adverse reactions in man to vaccines containing tetanus and diphtheria toxoids. Vaccine. 1998; 16:1016-1023. [PubMed: 9682353]

17. He Q, Mitchell A, Morcol T, Bell SJD. Calcium phosphate nanoparticles induce mucosal immunity and protection against herpes simplex virus type 2. Clinical and diagnostic laboratory immunology. 2002; 9:1021-1024. [PubMed: 12204953]

18. He Q, Mitchell AR, Johnson SL, Wagner-Bartak C, Morcol T, Bell SJ. Calcium phosphate nanoparticle adjuvant. Clinical and diagnostic laboratory immunology. 2000; 7:899-903. [PubMed: 11063495]

19. Masson J-D, Thibaudon M, Bélec L, Crépeaux G. Calcium phosphate: a substitute for aluminum adjuvants? Expert Review of Vaccines. 2017; 16:289-299. [PubMed: 27690701]

**20. Salk JE. The immunizing effect of calcium phosphate adsorbed influenza virus. Science. 1945; 101:122-124. One of Jonas Salk's first reports of the effects of in soluble metal salt on immune responses. [PubMed: 17799208]

**21. Walls RS. Eosinophil Response to Alum Adjuvants: Involvement of T Cells in Non-AntigenDependent Mechanisms. Experimental Biology and Medicine. 1977; 156:431-435. A first attemtp to find out how alum adjuvants affect immune responses.

22. Erdohazi M, Newman RL. Aluminium hydroxide granuloma. British medical journal. 1971; 3:621623. [PubMed: 5569985]

23. Beck W. Aluminum hydroxide granuloma after vaccination against tetanus. Die Medizinische. 1954; 11:363-365. [PubMed: 13164878]

**24. Munks MW, McKee AS, Macleod MK, Powell RL, Degen JL, Reisdorph NA, Kappler JW, Marrack P. Aluminum adjuvants elicit fibrin-dependent extracellular traps in vivo. Blood. 2010; 116:5191-5199. The first report that, after injection, fibrin and host chromatin are rapidly deposited on alum, a process that causes aggregation of the small alum pricipitates into large aggregates resembling neutrophil extracellular traps. [PubMed: 20876456]

Curr Opin Immunol. Author manuscript; available in PMC 2018 August 01. 
25. Brinkmann V, Reichard U, Goosmann C, Fauler B, Uhlemann Y, Weiss DS, Weinrauch Y, Zychlinsky A. Neutrophil extracellular traps kill bacteria. Science. 2004; 303:1532-1535. [PubMed: 15001782]

26. Urban CF, Reichard U, Brinkmann V, Zychlinsky A. Neutrophil extracellular traps capture and kill Candida albicans yeast and hyphal forms. Cell Microbiol. 2006; 8:668-676. [PubMed: 16548892]

27. Neeli I, Dwivedi N, Khan S, Radic M. Regulation of extracellular chromatin release from neutrophils. J Innate Immun. 2009; 1:194-201. [PubMed: 20375577]

28. Onouchi T, Shiogama K, Matsui T, Mizutani Y, Sakurai K, Inada K, Tsutsumi Y. Visualization of Neutrophil Extracellular Traps and Fibrin Meshwork in Human Fibrinopurulent Inflammatory Lesions: II. Ultrastructural Study. Acta Histochem Cytochem. 2016; 49:117-123. [PubMed: 27682015]

**29. Marichal T, Ohata K, Bedoret D, Mesnil C, Sabatel C, Kobiyama K, Lekeux P, Coban C, Akira $\mathrm{S}$, Ishii KJ, et al. DNA released from dying host cells mediates aluminum adjuvant activity. Nature Medicine. 2011; 17:996-1002. Intorduction of the idea that host DNA might contribute to the adjuvant properties of alum.

30. McKee AS, Burchill MA, Munks MW, Jin L, Kappler JW, Friedman RS, Jacobelli J, Marrack P. Host DNA released in response to aluminum adjuvant enhances MHC class II-mediated antigen presentation and prolongs CD4 T-cell interactions with dendritic cells. Proc Natl Acad Sci U S A. 2013; 110:E1122-1131. [PubMed: 23447566]

31. Nakayama T. An inflammatory response is essential for the development of adaptive immunityimmunogenicity and immunotoxicity. Vaccine. 2016; 34:5815-5818. [PubMed: 27745952]

32. Noges LE, White J, Cambier JC, Kappler JW, Marrack P. Contamination of DNase Preparations Confounds Analysis of the Role of DNA in Alum-Adjuvanted Vaccines. The Journal of Immunology. 2016; 197:1221-1230. [PubMed: 27357147]

**33. Jacobson LS, Lima H Jr, Goldberg MF, Gocheva V, Tsiperson V, Sutterwala FS, Joyce JA, Gapp BV, Blomen VA, Chandran K, et al. Cathepsin-mediated necrosis controls the adaptive immune response by Th2 (T helper type 2)-associated adjuvants. J Biol Chem. 2013; 288:7481-7491. Investigation of the TH2 biasing effects of some adjuvants. [PubMed: 23297415]

34. Lima H Jr, Jacobson LS, Goldberg MF, Chandran K, Diaz-Griffero F, Lisanti MP, Brojatsch J. Role of lysosome rupture in controlling Nlrp3 signaling and necrotic cell death. Cell Cycle. 2013; 12:1868-1878. [PubMed: 23708522]

**35. Hornung V, Bauernfeind F, Halle A, Samstad EO, Kono H, Rock KL, Fitzgerald KA, Latz E. Silica crystals and aluminum salts activate the NALP3 inflammasome through phagosomal destabilization. Nat Immunol. 2008; 9:847-856. Studies on another property of insoluble metal salst - their ability to desatabilize internal membranes. [PubMed: 18604214]

**36. Flach TL, Ng G, Hari A, Desrosiers MD, Zhang P, Ward SM, Seamone ME, Vilaysane A, Mucsi $\mathrm{AD}$, Fong Y, et al. Alum interaction with dendritic cell membrane lipids is essential for its adjuvanticity. Nature Medicine. 2011; 17:479-487. This study suggests that alum might function by changing the nature of plasma membrane lipids.

37. McKee AS, Munks MW, MacLeod MK, Fleenor CJ, Van Rooijen N, Kappler JW, Marrack P. Alum induces innate immune responses through macrophage and mast cell sensors, but these sensors are not required for alum to act as an adjuvant for specific immunity. J Immunol. 2009; 183:44034414. [PubMed: 19734227]

38. Mosca F, Tritto E, Muzzi A, Monaci E, Bagnoli F, Iavarone C, O'Hagan D, Rappuoli R, De Gregorio E. Molecular and cellular signatures of human vaccine adjuvants. Proc Natl Acad Sci U S A. 2008; 105:10501-10506. [PubMed: 18650390]

39. Eisenbarth SC, Colegio OR, O'Connor W, Sutterwala FS, Flavell RA. Crucial role for the Nalp3 inflammasome in the immunostimulatory properties of aluminium adjuvants. Nature. 2008; 453:1122-1126. Alum induces IL-1 production via the NLRP3 inflammasome and the Il-1 contributes to the adjuvant propoerties of alum. [PubMed: 18496530]

40. Li H, Nookala S, Re F. Aluminum hydroxide adjuvants activate caspase-1 and induce IL-1beta and IL-18 release. J Immunol. 2007; 178:5271-5276. [PubMed: 17404311] 
41. Franchi L, Nunez G. The Nlrp3 inflammasome is critical for aluminium hydroxide-mediated IL-1beta secretion but dispensable for adjuvant activity. Eur J Immunol. 2008; 38:2085-2089. [PubMed: 18624356]

42. Eisenbarth SC, Colegio OR, O'Connor W, Sutterwala FS, Flavell RA. Crucial role for the Nalp3 inflammasome in the immunostimulatory properties of aluminium adjuvants. Nature. 2008; 453:1122-1126. [PubMed: 18496530]

43. Li H, Willingham SB, Ting JPY, Re F. Cutting edge: inflammasome activation by alum and alum's adjuvant effect are mediated by NLRP3. Journal of immunology (Baltimore, Md. : 1950). 2008; 181:17-21.

44. Schmitz N, Kurrer M, Kopf M. The IL-1 receptor 1 is critical for Th2 cell type airway immune responses in a mild but not in a more severe asthma model. Eur J Immunol. 2003; 33:991-1000. [PubMed: 12672065]

45. Franchi L, Núñez G. The Nlrp3 inflammasome is critical for aluminium hydroxide-mediated IL-1 secretion but dispensable for secretion but dispensable for adjuvant acctivity. European Journal of Immunology. 2008; 38:2085-2089. [PubMed: 18624356]

46. Quandt D, Rothe K, Baerwald C, Rossol M, Spaner DE. GPRC6A mediates Alum-induced Nlrp3 inflammasome activation but limits Th2 type antibody responses. Scientific Reports. 2015; 5:16719-16719. [PubMed: 26602597]

47. Oleszycka E, Moran HBT, Tynan GA, Hearnden CH, Coutts G, Campbell M, Allan SM, Scott CJ, Lavelle EC. IL-1 and inflammassomee-independent IL-1 prromotee neutrophil infiltration following alum vaccination. FEBS Journal. 2016; 283:9-24. [PubMed: 26536497]

48. Schnare M, Barton GM, Holt AC, Takeda K, Akira S, Medzhitov R. Toll-like receptors control activation of adaptive immune responses. Nat Immunol. 2001; 2:947-950. [PubMed: 11547333]

*49. Gavin AL, Hoebe K, Duong B, Ota T, Martin C, Beutler B, Nemazee D. Adjuvant-enhanced antibody responses in the absence of toll-like receptor signaling. Science. 2006; 314:1936-1938. TLR signaling is not involved in alum's adjuvant properties. [PubMed: 17185603]

50. Matsushita K, Yoshimoto T. B cell-intrinsic MyD88 signaling is essential for IgE responses in lungs exposed to pollen allergens. J Immunol. 2014; 193:5791-5800. [PubMed: 25367117]

**51. Kuroda E, Ozasa K, Temizoz B, Ohata K, Koo CX, Kanuma T, Kusakabe T, Kobari S, Horie M, Morimoto Y, et al. Inhaled Fine Particles Induce Alveolar Macrophage Death and Interleukin-1alpha Release to Promote Inducible Bronchus-Associated Lymphoid Tissue Formation. Immunity. 2016; 45:1299-1310. Alveolar macrophages die in response to challenge. [PubMed: 28002730]

52. Snelgrove RJ, Goulding J, Didierlaurent AM, Lyonga D, Vekaria S, Edwards L, Gwyer E, Sedgwick JD, Barclay AN, Hussell T. A critical function for CD200 in lung immune homeostasis and the severity of influenza infection. Nat Immunol. 2008; 9:1074-1083. [PubMed: 18660812]

53. Janssen WJ, McPhillips KA, Dickinson MG, Linderman DJ, Morimoto K, Xiao YQ, Oldham KM, Vandivier RW, Henson PM, Gardai SJ. Surfactant proteins A and D suppress alveolar macrophage phagocytosis via interaction with SIRP alpha. Am J Respir Crit Care Med. 2008; 178:158-167. [PubMed: 18420961]

**54. Gibbings SL, Thomas SM, Atif SM, McCubbrey AL, Desch AN, Danhorn T, Leach SM, Bratton DL, Henson PM, Janssen WJ, et al. Three Unique Interstitial Macrophages in the Murine Lung at Steady State. Am J Respir Cell Mol Biol. 2017 Alveolar macrophages are intrinsically antiinflammatory.

55. McKee AS, Fontenot AP. Interplay of innate and adaptive immunity in metal-induced hypersensitivity. Curr Opin Immunol. 2016; 42:25-30. [PubMed: 27228132]

56. McKee AS, Mack DG, Crawford F, Fontenot AP. MyD88 dependence of beryllium-induced dendritic cell trafficking and CD4(+) T-cell priming. Mucosal Immunol. 2015; 8:1237-1247. [PubMed: 25760420]

**57. Brewer JM, Conacher M, Satoskar A, Bluethmann H, Alexander J. In interleukin-4-deficient mice, alum not only generates $\mathrm{T}$ helper 1 responses equivalent to freund's complete adjuvant, but continues to induce T helper 2 cytokine production. Eur J Immunol. 1996; 26:2062-2066. One of the first reports that alum preferentially induces TH2 responses. [PubMed: 8814247]

Curr Opin Immunol. Author manuscript; available in PMC 2018 August 01. 
58. Hamaoka T. Hapten specific IgE antibody responses in mice: Secondary IgE responses in irradiated recipients of syngeneic primed spleen cells. Journal of Experimental Medicine. 1973; 138:306-311. [PubMed: 4541510]

59. Brewer JM, Conacher M, Hunter CA, Mohrs M, Brombacher F, Alexander J. Aluminium hydroxide adjuvant initiates strong antigen-specific Th2 responses in the absence of IL-4- or IL-13-mediated signaling. Journal of Immunology. 1999; 163:6448-6454.

60. van Halteren AG, van der Cammen MJ, Biewenga J, Savelkoul HF, Kraal G. IgE and mast cell response on intestinal allergen exposure: a murine model to study the onset of food allergy. $\mathrm{J}$ Allergy Clin Immunol. 1997; 99:94-99. [PubMed: 9003216]

61. MacLeod MK, David A, McKee AS, Crawford F, Kappler JW, Marrack P. Memory CD4 T cells that express CXCR5 provide accelerated help to B cells. J Immunol. 2011; 186:2889-2896. [PubMed: 21270407]

62. Serre K, Mohr E, Benezech C, Bird R, Khan M, Caamano JH, Cunningham AF, Maclennan IC. Selective effects of NF-kappaB1 deficiency in CD4(+) T cells on Th2 and TFh induction by alumprecipitated protein vaccines. Eur J Immunol. 2011; 41:1573-1582. [PubMed: 21469117]

63. Pene J, Gauchat JF, Lecart S, Drouet E, Guglielmi P, Boulay V, Delwail A, Foster D, Lecron JC, Yssel H. Cutting edge: IL-21 is a switch factor for the production of IgG1 and IgG3 by human B cells. J Immunol. 2004; 172:5154-5157. [PubMed: 15100251]

64. Mori A, Oleszycka E, Sharp FA, Coleman M, Ozasa Y, Singh M, O'Hagan DT, Tajber L, Corrigan OI, McNeela EA, et al. The vaccine adjuvant alum inhibits IL-12 by promoting PI3 kinase signaling while chitosan does not inhibit IL-12 and enhances Th1 and Th17 responses. European Journal of Immunology. 2012; 42:2709-2719. [PubMed: 22777876]

**65. Opie EL, Freund J. An Experimental Study of Protective Inoculation with Heat Killed Tubercle Bacilli. J Exp Med. 1937; 66:761-788. The introduction of oil based emulsions as adjuvants. [PubMed: 19870697]

66. Chase M. The cellular transfer of cutaneous hypersensitivity to tuberculin. Proc Soc Exp Biol Med. 1945; 59:134-135.

67. Ellouz F, Adam A, Ciorbaru R, Lederer E. Minimal structural requirements for adjuvant activity of bacterial peptidoglycan derivatives. Biochem Biophys Res Commun. 1974; 59:1317-1325.

[PubMed: 4606813]

**68. Girardin SE, Boneca IG, Viala J, Chamaillard M, Labigne A, Thomas G, Philpott DJ, Sansonetti PJ. Nod2 is a general sensor of peptidoglycan through muramyl dipeptide (MDP) detection. J Biol Chem. 2003; 278:8869-8872. The discovery of cytoplasmic receptors for bacterial products. [PubMed: 12527755]

69. Salk JE, Laurent AM. The use of adjuvants in studies on influenza immunization. I. Measurements in monkeys of the dimensions of antigenicity of virus-mineral oil emulsions. J Exp Med. 1952; 95:429-447. [PubMed: 14927797]

70. Miller LH, Saul A, Mahanty S. Revisiting Freund's incomplete adjuvant for vaccines in the developing world. Trends Parasitol. 2005; 21:412-414. [PubMed: 16043410]

71. Apostolico, JdeS, Lunardelli, VA., Coirada, FC., Boscardin, SB., Rosa, DS. Adjuvants: Classification, Modus Operandi, and Licensing. J Immunol Res. 2016; 2016:1459394. [PubMed: 27274998]

72. Mussener A, Klareskog L, Lorentzen JC, Kleinau S. TNF-alpha dominates cytokine mRNA expression in lymphoid tissues of rats developing collagen- and oil-induced arthritis. Scand J Immunol. 1995; 42:128-134. [PubMed: 7631134]

73. Shibaki A, Katz SI. Induction of skewed Th1/Th2 T-cell differentiation via subcutaneous immunization with Freund's adjuvant. Exp Dermatol. 2002; 11:126-134. [PubMed: 11994139]

74. Yip HC, Karulin AY, Tary-Lehmann M, Hesse MD, Radeke H, Heeger PS, Trezza RP, Heinzel FP, Forsthuber T, Lehmann PV. Adjuvant-guided type-1 and type-2 immunity: infectious/ noninfectious dichotomy defines the class of response. J Immunol. 1999; 162:3942-3949. [PubMed: 10201913]

75. Karagouni EE, Hadjipetrou-Kourounakis L. Regulation of isotype immunoglobulin production by adjuvants in vivo. Scand J Immunol. 1990; 31:745-754. [PubMed: 1694039] 
**76. Hadjipetrou-Kourounakis L, Moller E. Adjuvants influence the immunoglobin subclass distribution of immune responses in vivo. Scand J Immunol. 1984; 19:219-225. The nature of the vaccine adjuvant affects the isotype of antibodies produced. [PubMed: 6424231]

**77. O'Hagan DT, Wack A, Podda A. MF59 is a safe and potent vaccine adjuvant for flu vaccines in humans: what did we learn during its development? Clin Pharmacol Ther. 2007; 82:740-744. Review of the use of squalene based adjuvants in human vaccines. [PubMed: 17971820]

78. Vesikari T, Forsten A, Herbinger KH, Cioppa GD, Beygo J, Borkowski A, Groth N, Bennati M, von Sonnenburg F. Safety and immunogenicity of an MF59((R))-adjuvanted A/H5N1 prepandemic influenza vaccine in adults and the elderly. Vaccine. 2012; 30:1388-1396. [PubMed: 22192847]

79. Vesikari T, Knuf M, Wutzler P, Karvonen A, Kieninger-Baum D, Schmitt HJ, Baehner F, Borkowski A, Tsai TF, Clemens R. Oil-in-water emulsion adjuvant with influenza vaccine in young children. N Engl J Med. 2011; 365:1406-1416. [PubMed: 21995388]

80. Garcon N, Vaughn DW, Didierlaurent AM. Development and evaluation of AS03, an Adjuvant System containing alpha-tocopherol and squalene in an oil-in-water emulsion. Expert Rev Vaccines. 2012; 11:349-366. [PubMed: 22380826]

81. Nakaya HI, Clutterbuck E, Kazmin D, Wang L, Cortese M, Bosinger SE, Patel NB, Zak DE, Aderem A, Dong T, et al. Systems biology of immunity to MF59-adjuvanted versus nonadjuvanted trivalent seasonal influenza vaccines in early childhood. Proc Natl Acad Sci U S A. 2016; 113:1853-1858. [PubMed: 26755593]

82. Mastelic Gavillet B, Eberhardt CS, Auderset F, Castellino F, Seubert A, Tregoning JS, Lambert PH, de Gregorio E, Del Giudice G, Siegrist CA. MF59 Mediates Its B Cell Adjuvanticity by Promoting T Follicular Helper Cells and Thus Germinal Center Responses in Adult and Early Life. J Immunol. 2015; 194:4836-4845. [PubMed: 25870238]

83. Ko EJ, Lee YT, Kim KH, Jung YJ, Lee Y, Denning TL, Kang SM. Effects of MF59 Adjuvant on Induction of Isotype-Switched IgG Antibodies and Protection after Immunization with TDependent Influenza Virus Vaccine in the Absence of CD4+ T Cells. J Virol. 2016; 90:6976-6988. [PubMed: 27226368]

84. Ellebedy AH, Lupfer C, Ghoneim HE, DeBeauchamp J, Kanneganti TD, Webby RJ. Inflammasome-independent role of the apoptosis-associated speck-like protein containing CARD (ASC) in the adjuvant effect of MF59. Proceedings of the National Academy of Sciences. 2011; 108:2927-2932.

**85. Seubert A, Calabro S, Santini L, Galli B, Genovese A, Valentini S, Aprea S, Colaprico A, D'Oro U, Giuliani MM, et al. Adjuvanticity of the oil-in-water emulsion MF59 is independent of Nlrp3 inflammasome but requires the adaptor protein MyD88. Proceedings of the National Academy of Sciences. 2011; 108:11169-11174. Unexpected independence of a squalene based adjuvant.

86. Caproni E, Tritto E, Cortese M, Muzzi A, Mosca F, Monaci E, Baudner B, Seubert A, De Gregorio E. MF59 and Pam3CSK4 Boost Adaptive Responses to Influenza Subunit Vaccine through an IFN Type I-Independent Mechanism of Action. The Journal of Immunology. 2012; 188:3088-3098. [PubMed: 22351935]

87. Vono M, Taccone M, Caccin P, Gallotta M, Donvito G, Falzoni S, Palmieri E, Pallaoro M, Rappuoli R, Di Virgilio F, et al. The adjuvant MF59 induces ATP release from muscle that potentiates response to vaccination.

88. Kaisho T, Akira S. Toll-like receptors as adjuvant receptors. Biochim Biophys Acta. 2002; 1589:113. [PubMed: 11909637]

**89. Janeway C. Approaching the asymptote? Evolution and revolution in immunology. Cold Spring Harbor Symp Quantit Biol. 1989; 54:1-13. Janeway's historic discussion of immunologists' dirty little secret, the need for adjuvants for immunogenicity.

90. Inaba K, Turley S, Iyoda T, Yamaide F, Shimoyama S, Reis e Sousa C, Germain RN, Mellman I, Steinman RM. The formation of immunogenic major histocompatibility complex class II-peptide ligands in lysosomal compartments of dendritic cells is regulated by inflammatory stimuli. J Exp Med. 2000; 191:927-936. [PubMed: 10727455]

91. Steinman RM, Pope M. Exploiting dendritic cells to improve vaccine efficacy. J Clin Invest. 2002; 109:1519-1526. [PubMed: 12070296] 
92. Akondy RS, Monson ND, Miller JD, Edupuganti S, Teuwen D, Wu H, Quyyumi F, Garg S, Altman JD, Del Rio C, et al. The yellow fever virus vaccine induces a broad and polyfunctional human memory CD8+ T cell response. J Immunol. 2009; 183:7919-7930. [PubMed: 19933869]

93. Barbuto S, Idoyaga J, Vila-Perello M, Longhi MP, Breton G, Steinman RM, Muir TW. Induction of innate and adaptive immunity by delivery of poly dA:dT to dendritic cells. Nat Chem Biol. 2013; 9:250-256. [PubMed: 23416331]

94. Soares H, Waechter H, Glaichenhaus N, Mougneau E, Yagita H, Mizenina O, Dudziak D, Nussenzweig MC, Steinman RM. A subset of dendritic cells induces CD4+ T cells to produce IFN-gamma by an IL-12-independent but CD70-dependent mechanism in vivo. J Exp Med. 2007; 204:1095-1106. [PubMed: 17438065]

95. Cheong C, Choi JH, Vitale L, He LZ, Trumpfheller C, Bozzacco L, Do Y, Nchinda G, Park SH, Dandamudi DB, et al. Improved cellular and humoral immune responses in vivo following targeting of HIV Gag to dendritic cells within human anti-human DEC205 monoclonal antibody. Blood. 2010; 116:3828-3838. [PubMed: 20668230]

96. Idoyaga J, Lubkin A, Fiorese C, Lahoud MH, Caminschi I, Huang Y, Rodriguez A, Clausen BE, Park CG, Trumpfheller C, et al. Comparable T helper 1 (Th1) and CD8 T-cell immunity by targeting HIV gag p24 to CD8 dendritic cells within antibodies to Langerin, DEC205, and Clec9A. Proc Natl Acad Sci U S A. 2011; 108:2384-2389. [PubMed: 21262813]

97. Flynn BJ, Kastenmuller K, Wille-Reece U, Tomaras GD, Alam M, Lindsay RW, Salazar AM, Perdiguero B, Gomez CE, Wagner R, et al. Immunization with HIV Gag targeted to dendritic cells followed by recombinant New York vaccinia virus induces robust T-cell immunity in nonhuman primates. Proc Natl Acad Sci U S A. 2011; 108:7131-7136. [PubMed: 21467219]

98. Henriques HR, Rampazo EV, Goncalves AJ, Vicentin EC, Amorim JH, Panatieri RH, Amorim KN, Yamamoto MM, Ferreira LC, Alves AM, et al. Targeting the non-structural protein 1 from dengue virus to a dendritic cell population confers protective immunity to lethal virus challenge. PLoS Negl Trop Dis. 2013; 7:e2330. [PubMed: 23875054]

99. Didierlaurent AM, Morel S, Lockman L, Giannini SL, Bisteau M, Carlsen H, Kielland A, Vosters O, Vanderheyde N, Schiavetti F, et al. AS04, an aluminum salt- and TLR4 agonist-based adjuvant system, induces a transient localized innate immune response leading to enhanced adaptive immunity. J Immunol. 2009; 183:6186-6197. [PubMed: 19864596]

100. Orr MT, Fox CB, Baldwin SL, Sivananthan SJ, Lucas E, Lin S, Phan T, Moon JJ, Vedvick TS, Reed SG, et al. Adjuvant formulation structure and composition are critical for the development of an effective vaccine against tuberculosis. J Control Release. 2013; 172:190-200. [PubMed: 23933525]

101. Buonsanti C, Balocchi C, Harfouche C, Corrente F, Galli Stampino L, Mancini F, Tontini M, Malyala P, Bufali S, Baudner B, et al. Novel adjuvant Alum-TLR7 significantly potentiates immune response to glycoconjugate vaccines. Sci Rep. 2016; 6:29063. [PubMed: 27439378]

102. Ismaili J, Rennesson J, Aksoy E, Vekemans J, Vincart B, Amraoui Z, Van Laethem F, Goldman M, Dubois PM. Monophosphoryl lipid A activates both human dendritic cells and T cells. J Immunol. 2002; 168:926-932. [PubMed: 11777991]

103. Gandhapudi SK, Chilton PM, Mitchell TC. TRIF is required for TLR4 mediated adjuvant effects on T cell clonal expansion. PLoS One. 2013; 8:e56855. [PubMed: 23457630]

104. Thompson BS, Chilton PM, Ward JR, Evans JT, Mitchell TC. The low-toxicity versions of LPS, MPL adjuvant and RC529, are efficient adjuvants for CD4+ T cells. J Leukoc Biol. 2005; 78:1273-1280. [PubMed: 16204643]

105. Mbawuike IN, Acuna C, Caballero D, Pham-Nguyen K, Gilbert B, Petribon P, Harmon M. Reversal of age-related deficient influenza virus-specific CTL responses and IFN-gamma production by monophosphoryl lipid A. Cell Immunol. 1996; 173:64-78. [PubMed: 8871602]

106. Pantel A, Cheong C, Dandamudi D, Shrestha E, Mehandru S, Brane L, Ruane D, Teixeira A, Bozzacco L, Steinman RM, et al. A new synthetic TLR4 agonist, GLA, allows dendritic cells targeted with antigen to elicit Th1 T-cell immunity in vivo. Eur J Immunol. 2012; 42:101-109. [PubMed: 22002164]

107. Tanimura N, Saitoh S, Ohto U, Akashi-Takamura S, Fujimoto Y, Fukase K, Shimizu T, Miyake K. The attenuated inflammation of MPL is due to the lack of CD14-dependent tight dimerization of 
the TLR4/MD2 complex at the plasma membrane. Int Immunol. 2014; 26:307-314. [PubMed: 24380872]

108. Bowen WS, Minns LA, Johnson DA, Mitchell TC, Hutton MM, Evans JT. Selective TRIFdependent signaling by a synthetic toll-like receptor 4 agonist. Sci Signal. 2012; 5:ra13. [PubMed: 22337809]

109. Coler RN, Bertholet S, Moutaftsi M, Guderian JA, Windish HP, Baldwin SL, Laughlin EM, Duthie MS, Fox CB, Carter D, et al. Development and characterization of synthetic glucopyranosyl lipid adjuvant system as a vaccine adjuvant. PLoS One. 2011; 6:e16333. [PubMed: 21298114]

110. Dubois Cauwelaert N, Desbien AL, Hudson TE, Pine SO, Reed SG, Coler RN, Orr MT. The TLR4 Agonist Vaccine Adjuvant, GLA-SE, Requires Canonical and Atypical Mechanisms of Action for TH1 Induction. PLoS One. 2016; 11:e0146372. [PubMed: 26731269]

111. Orr MT, Duthie MS, Windish HP, Lucas EA, Guderian JA, Hudson TE, Shaverdian N, O'Donnell J, Desbien AL, Reed SG, et al. MyD88 and TRIF synergistic interaction is required for TH1-cell polarization with a synthetic TLR4 agonist adjuvant. Eur J Immunol. 2013; 43:2398-2408. [PubMed: 23716300]

112. Desbien AL, Dubois Cauwelaert N, Reed SJ, Bailor HR, Liang H, Carter D, Duthie MS, Fox CB, Reed SG, Orr MT. IL-18 and Subcapsular Lymph Node Macrophages are Essential for Enhanced B Cell Responses with TLR4 Agonist Adjuvants. Journal of immunology (Baltimore, Md. : 1950). 2016; 197:4351-4359.

113. Querec T, Bennouna S, Alkan S, Laouar Y, Gorden K, Flavell R, Akira S, Ahmed R, Pulendran B. Yellow fever vaccine YF-17D activates multiple dendritic cell subsets via TLR2, 7, 8, and 9 to stimulate polyvalent immunity. J Exp Med. 2006; 203:413-424. [PubMed: 16461338]

114. Kasturi SP, Skountzou I, Albrecht RA, Koutsonanos D, Hua T, Nakaya HI, Ravindran R, Stewart S, Alam M, Kwissa M, et al. Programming the magnitude and persistence of antibody responses with innate immunity. Nature. 2011; 470:543-547. [PubMed: 21350488]

115. Apostolico, JdeS, Boscardin, SB., Yamamoto, MM., de Oliveira-Filho, JN., Kalil, J., Cunha-Neto, E., Rosa, DS. HIV Envelope Trimer Specific Immune Response Is Influenced by Different Adjuvant Formulations and Heterologous Prime-Boost. PLoS One. 2016; 11:e0145637. [PubMed: 26727218]

116. MacLeod MK, McKee AS, David A, Wang J, Mason R, Kappler JW, Marrack P. Vaccine adjuvants aluminum and monophosphoryl lipid A provide distinct signals to generate protective cytotoxic memory CD8 T cells. Proc Natl Acad Sci U S A. 2011; 108:7914-7919. [PubMed: 21518876] 


\section{Highlights}

- $\quad$ Aluminum salts are amongst the oldest approved adjuvant and drive proliferation of $\mathrm{CD}^{+}$(TH2 and $\mathrm{TFH}$ ) cells, $\mathrm{CD} 8^{+} \mathrm{T}$ cell priming and type 2 antibody responses and induce CTL-mediated protection if MPL is added

- $\quad$ The requirement for IL-1/MyD88 in the development of antibody responses to aluminum adjuvants depends on the site of adjuvant exposure

- $\quad$ Emulsions containing squalene enhance T cell responses via a MyD88 dependent pathway and promote heterotypic immunity by enhancing germinal center reactions

- New strategies that combine TLR agonists and older adjuvants (alum, liposomes or emulsions) drive potent antibody and cell-mediated immunity 


\begin{tabular}{|c|c|}
\hline Adjuvant & Vaccines \\
\hline \multicolumn{2}{|l|}{ Mineral Salts } \\
\hline Aluminum salts ASO4 (alum + MPL) & $\begin{array}{l}\text { DT, DTaP, HVA, HBV, HPV (AS04 - see below), HIB, } \\
\text { Meningococcus, Pneumococcus, IPV HAV, HPV }\end{array}$ \\
\hline Calcium Phosphate & DT, DTaP, IPV \\
\hline \multicolumn{2}{|l|}{ Delivery systems } \\
\hline Virus-like particles & $\begin{array}{l}\text { HBV, HPV, in clinical trials for HAV, HCV, malaria, HIV, } \\
\text { HPV, malaria, norovirus }\end{array}$ \\
\hline Liposomes & $\begin{array}{l}\text { HBV, HPV, in clinical trials for Hepatitis A,C, malaria, } \\
\text { HIV, HPV, malaria, Norovirus }\end{array}$ \\
\hline Microparticles (PLA/PLGA) & Malaria HPV, HBV \\
\hline \multicolumn{2}{|l|}{ Emulsions } \\
\hline IFA (water-in oil emulsion) & Influenza (1950s) \\
\hline AS02 (MPL+QS21 in oil-in water emulsion) & Malaria \\
\hline \multicolumn{2}{|l|}{ Squalene } \\
\hline MF59 & Influenza \\
\hline $\mathrm{ASO} 3$ & AS03 - in clinical trial for HPV and malaria \\
\hline \multicolumn{2}{|l|}{ TLR agonists } \\
\hline MPL-SE & Influenza (MPL) \\
\hline AS04 (MPL + Alum) & HPV, HBV, \\
\hline \multicolumn{2}{|l|}{ AS01 (MPL+QS21 in liposomes) } \\
\hline AS02 (MPL+QS21 in oil-in water emulsion) & Malaria \\
\hline GLA, GLA-SE & In clinical development for Mtb, Influenza, Leishmaniasis \\
\hline
\end{tabular}

Abbreviations: (DT, diphtheria/pertussis, DTaP (DT with acellular pertussis); HAV, hepatitis A virus; HBV; hepatitis B virus; HPV, human papilloma virus; HIB, haemophillus influenza type B virus; IPV, inactivated polio vaccine; MPL, monophosporyl lipid a; GLA, glucopyrosyl lipid adjuvant

\begin{tabular}{|llll|}
\hline Adjuvant & Innate responses & Effects on DC & Type of immune response \\
\hline Aluminum salts & $\begin{array}{l}\text { Nlrp3/P2X7R/ } \\
\text { neutrophil }\end{array}$ & $\begin{array}{l}\uparrow \text { migration to LN } \\
\text { (ip) }\end{array}$ & $\mathrm{TH} 2$ \\
& $\begin{array}{l}\text { recruitment, DAMP } \\
\text { release: (chromatin, }\end{array}$ & $\uparrow$ T cell interactions & $\mathrm{TFH}$ \\
& histones, IL-1a, & $\uparrow$ antigen presentation & $\uparrow$ IgG1/IgE \\
& NETs, uric acid) & $\downarrow$ IL-12 secretion & \\
& Tependent effects on & Reorganization of \\
& membrane lipids & \\
& &
\end{tabular}

Curr Opin Immunol. Author manuscript; available in PMC 2018 August 01. 


\begin{tabular}{|c|c|c|c|}
\hline Adjuvant & Innate responses & Effects on DC & Type of immune response \\
\hline \multirow[t]{4}{*}{ Emulsions } & $\begin{array}{l}\text { Increases delivery to } \\
\text { APC }\end{array}$ & \multirow[t]{4}{*}{$\uparrow$ antigen presentation } & TH1/TH2 \\
\hline & $\uparrow$ phagocytosis & & \multirow[t]{3}{*}{$\uparrow \mathrm{IgG} 1 / \mathrm{IgG} 2 \mathrm{a}$} \\
\hline & $\begin{array}{l}\uparrow \text { infiltration of } \\
\text { monocytes }\end{array}$ & & \\
\hline & $\uparrow$ cytokine production & & \\
\hline \multirow[t]{4}{*}{ MF59 } & \multirow{4}{*}{$\begin{array}{l}\text { Monocyte } \\
\text { recruitment, NLRP3 } \\
\text { activation (not } \\
\text { required for adjuvant } \\
\text { effects), DAMP } \\
\text { release: ATP MyD88- } \\
\text { dependent effects on } \\
\text { cellular immunity }\end{array}$} & $\begin{array}{l}\uparrow \text { migration to LN } \\
\text { (ip) }\end{array}$ & Polyfunctional TH1 \\
\hline & & \multirow{3}{*}{$\begin{array}{l}\uparrow \text { expression of } \\
\text { costimulatory } \\
\text { molecules }\end{array}$} & $\mathrm{TFH}$ \\
\hline & & & $\uparrow \mathrm{IgG} 2 \mathrm{a}, \mathrm{IgG} 1$ \\
\hline & & & $\uparrow$ antibody diversity/switching \\
\hline \multirow[t]{3}{*}{ MPL } & $\begin{array}{l}\text { TLR4/TRIF and type } \\
\text { I IFNs }\end{array}$ & \multirow{2}{*}{$\begin{array}{l}\uparrow \text { expression } \\
\text { costimulatory } \\
\text { molecules and } \\
\text { cytokines }\end{array}$} & TH1 \\
\hline & $\begin{array}{l}\text { Migration of } \\
\text { monocytes to } \\
\text { injection site }\end{array}$ & & $\mathrm{TFH}$ \\
\hline & & $\uparrow$ antigen presentation & $\mathrm{CTL}$ and \\
\hline \multirow[t]{3}{*}{ GLA } & TLR4/MyD88+TRIF & & \\
\hline & $\begin{array}{l}\text { IL-18 from } \\
\text { subcapsular } \\
\text { macrophages }\end{array}$ & \multirow[t]{2}{*}{$\begin{array}{l}\uparrow \text { phagocytosis and } \\
\text { endosomal activity }\end{array}$} & \multirow[t]{2}{*}{$\begin{array}{l}\uparrow \text { antibody diversity and } \\
\text { affinity }\end{array}$} \\
\hline & IL-12 and type I IFNs & & \\
\hline
\end{tabular}

